\title{
Aquatic systems in and adjacent to Agulhas National Park with particular reference to the fish fauna
}

\section{I.A. RUSSELL and N.D. IMPSON}

Russell, I.A. and N.D. Impson. 2006. Aquatic systems in and adjacent to Agulhas National Park with particular reference to the fish fauna. Koedoe 49(2): 45-57. Pretoria. ISSN 0075-6458.

The study aimed to determine the distribution and relative abundance of freshwater fishes in and adjacent to Agulhas National Park. Fourteen fish species were collected during surveys carried out in the Heuningnes and Ratel river systems and a variety of endorheic pans from 2003 to 2005. Seven of the species are marine fishes tolerant of low salinity (Mugil cephalus, Liza richardsonii, Monodactylus falciformis, Caffrogobius gilchristi, Rhabdosargus holubi, Solea bleekeri, Gilchristella aestuaria) with the remaining seven species being primary freshwater fishes. Three are indigenous, including Pseudobarbus burchelli, Sandelia capensis, and Galaxias zebratus of which two morphological forms were recorded within Agulhas National Park. The remaining four species are invasive aliens (Cyprinus carpio, Lepomis macrochirus, Micropterus salmoides, Micropterus punctulatus). Classification using physico-chemical variables indicated four major wetland groups, with fishes occurring predominantly in the group comprising palustrine, lacustrine and riverine wetlands, and in one instance in a brackish endorheic pan. Management actions which should facilitate conservation of indigenous fishes in the Agulhas region are suggested.

Key words: diversity, freshwater fish, conservation, wetlands, Agulhas National Park, Soetendalsvlei, Heuningnes River, Nuwejaars River, Ratel River.

I.A. Russell, South African National Parks, P.O. Box 176, Sedgefield, 6573. South Africa; N.D. Impson, Scientific Services, Western Cape Nature Conservation Board, Jonkershoek, Stellenbosch, 7600 South Africa.

\section{Introduction}

The Agulhas plain at the southern tip of Africa has been recognised as an area of high conservation importance for both terrestrial plants (Rebello \& Siegfried 1992; Cowling \& Mustart 1994; Cowling et al. 1999) and wetland biota (De Villiers 1988; Ryan et al. 1988; Rebelo 1992). The Heuningnes River system is recognised as a priority system for freshwater fish conservation in the Cape Floristic Region (Impson et al. 1999). Formal conservation of the area commenced in September 1999 with the proclamation of the Agulhas National Park (ANP). There is an ongoing park expansion program with the objective of including representative examples of both terrestrial and aquatic ecosystems. Where the terrestrial vegetation of the region has been the subject of intensive research (e.g., Cowling et al. 1988; Cowling \& Holmes 1992a; Willis et al. 1996; Cole et al. 2000), studies of aquatic systems have mostly been once-off assessments (Silberhauer \& King 1991; Jones et al. 2000) and concentrated predominantly on water chemistry. There are few accounts of aquatic biota, though the area is recognised as supporting a diverse aquatic macro-invertebrate fauna (J. King pers. comm.). The objective of this study was to improve understanding of the aquatic biota of the region, specifically by describing the diversity and distribution of fishes in and adjacent to the park. The in-park surveys also form a component of a long-term research program to assess the contribution national parks in South Africa make towards the conservation of South 


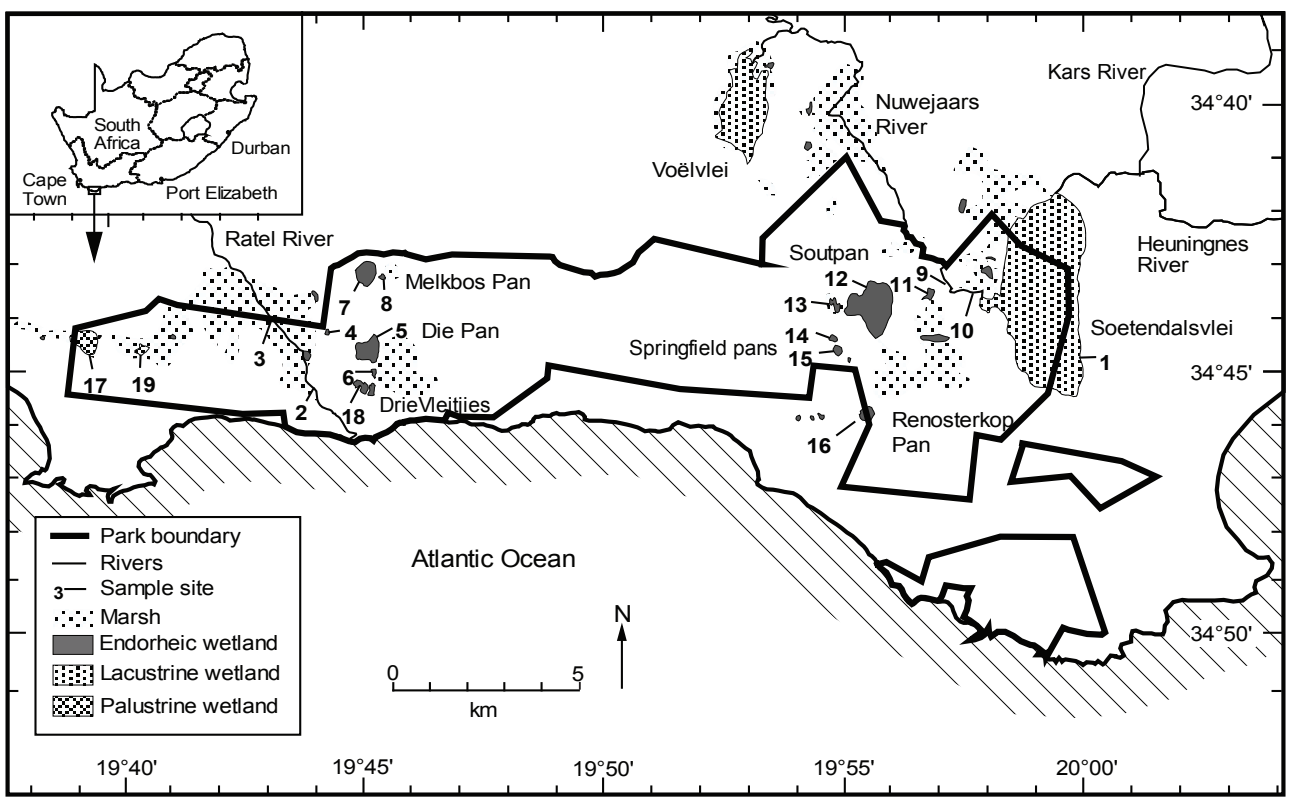

Fig. 1. Map of the Agulhas National Park indicating sites used to sample fish assemblages.

African freshwater fishes. The off-park surveys formed component of the Overberg river-health survey which is part of the South African River Health Program, the main purpose of which is to serve as a source of information regarding the overall ecological status of river ecosystems in South Africa.

\section{Study Area}

The ANP is situated between latitude $34^{\circ} 40^{\prime} \mathrm{S}-$ $34^{\circ} 50^{\prime} \mathrm{S}$ and longitude $19^{\circ} 38^{\prime} \mathrm{E}-20^{\circ} 02^{\prime} \mathrm{E}$ in the Western Cape province of South Africa, and covers an area of approximately 16807 ha. Typical rainfall is $450-480 \mathrm{~mm} / \mathrm{y}$ (Cowling \& Witkowski 1994), with more than $65 \%$ falling in winter between May and October (Thwaites \& Cowling 1988). Three different geological substrates occur in the Agulhas area, namely Bokkeveld Shale (Voëlvlei) Malmesbury Shale (Soutpan and Buffeljacht Pan) and Bredasdorp Limestone (Die Pan) (Carr 2005). Soil types in the Agulhas area are highly varied, ranging from coarse sands along the coast, alluvial or colluvial topsoils over residual or transported clays in the east, grey calcareous sands in the central areas, and acidic, highly leached, soils in western areas (Thwaites \& Cowling 1988). Terrestrial vegetation is extremely diverse ( $>1750$ species) with pronounced edaphic endemism, and consists of stands of Restioid Fynbos, Dune Fynbos, Limestone Fynbos, Acid sand Proteoid Fynbos, Ericaceous Fynbos, and Renosterveld (Cowling \& Holmes 1992b; Low \& Rebelo 1996). Wet Restioid Fynbos is frequently found on the low-lying, seasonally waterlogged areas, and around larger pans Phragmites reeds dominate (Mustart et al. 1997).

The main river systems in and adjacent to the ANP are the Heuningnes and Ratel. The Heuningnes River has two major tributaries, the Nuwejaars and Kars rivers. The Nuwejaars River flows through the north-eastern reaches of the park into Soetendalsvlei. Mean annual runoff (MAR) is $37.6 \times 10^{6} \mathrm{~m}^{3}$ (Raimondo \& Barker 1988). Large seasonally inundated wetlands are associated with its valley, though most occur outside the park. Soeten- 
dalsvlei is connected to the Indian Ocean via the Heuningnes River. The Kars River arises on the northern slopes of the Soetmuisberg and Bredasdorp mountains before flowing southwards and entering Karsriviervlei and the Heuningnes River, near the park. The Ratel River in the western reaches of ANP is a much smaller system, with a MAR of 7.05 $x 10^{6} \mathrm{~m}^{3}$ (Raimondo \& Barker 1988). Extensive wetlands occur along its lower reaches before it flows into the Atlantic Ocean.

Several endorheic pans occur within the park. They have been formed and are maintained by the interplay of a variety of geomorphological processes, including drainage disruption, aeolian activity, and the solution and weathering of the substrate (Goudie 1991; Marshall $\&$ Harmse 1992; Shaw \& Thomas 1997). The larger bodies of water such as Soetendalsvlei and Voëlvlei, which are directly connected to the Nuwejaars River, are lake-like in that they remain inundated year round. Many of the smaller pans are not connected to any fluvial system or only have small locally sourced channels entering them. They are ephemeral with an annual inundation/drying regime - a function of winter rainfall and subsequent summer evaporation.

Soetendalsvlei (sample site 1) is described by Silberbauer \& King (1991) as moderately saline $(2-5 \mathrm{~g} / \mathrm{kg})$, whereas several of the smaller pans (for example, sample site 12 Soutpan, sample site 7 Melkbospan, and sample site 6 Vispan) are strongly saline (16$86 \mathrm{~g} / \mathrm{kg})$. River waters are brackish $(<2 \mathrm{~g} / \mathrm{kg}$ salts) and alkaline as a result of passage through limestone-bearing Strandvlei sands (Noble \& Hemens 1978). The $\mathrm{pH}$ in most of the lowland wetlands varies between 6 and 8 (Silberbauer \& King 1991), though in Soetendalsvlei $\mathrm{pH}$ of up to 8.5 has been recorded (Noble \& Hemens 1978).

\section{Methods}

Surveys were undertaken by SANParks personnel within Agulhas National Park, forming the main component of this assessment, and by Western Cape River Health practitioners in rivers outside of ANP as part of a broad survey of rivers of the Overberg region. For the SANParks assessment, 19 sample sites were used of which three were in the Nuwejaars River system, two in the Ratel River system, and the remaining 14 in pans (Fig. 1). Fish sampling and water quality assessments were undertaken from 1-5 December 2003 (sample sites 1-18) and on 11 March 2004 (sample site 19). For the river-health assessment, seven sample sites were surveyed in the Heuningnes River system (Fig. 2) on 12 October 2005. Consecutive numbers after a hash symbol were assigned to different pans with the same name, for example Melkbospan \# 1 and Melkbospan \#2, to differentiate between sample sites.

Water quality parameters measured in the field at the time of fish sampling in ANP were: water temperature $\left({ }^{\circ} \mathrm{C}\right)$ and salinity $(\mathrm{g} / \mathrm{kg})$ using a YSI Model $33 \mathrm{~S}-\mathrm{C}-\mathrm{T}$ meter; dissolved oxygen $(\mathrm{mg} / \mathrm{l})$ using a YSI $550 \mathrm{~A} \mathrm{O}_{2}$ meter; and $\mathrm{pH}$ (YSI $60 \mathrm{pH}$ meter). Water samples were transported to a laboratory where turbidity (NTU) was measured with a Hach 16800 turbidimeter. Parameters measured in the Heuningnes River system during river-health assessments were conductivity ( $\mu$ mhos), $\mathrm{pH}$ and dissolved oxygen $(\mathrm{mg} / \mathrm{l})$ using portable YSI meters.

Sampling for fishes in Soetendalsvlei (sample site 1) was done with two brown multifilament gillnets $(40 \mathrm{~m}$ $\times 2 \mathrm{~m} \times 55 \mathrm{~mm}$ and $80 \mathrm{~mm}$ ) and one monofilament gillnet $(20 \mathrm{~m} \times 2 \mathrm{~m} \times 100 \mathrm{~mm})$, a beach seine net $(40 \mathrm{~m}$ $\times 3 \mathrm{~m} \times 3 \mathrm{~mm}$ ), with $50 \mathrm{~m}$ warps, and baited longlines (two $20 \mathrm{~m}$ lines each with 20 hooks). Gillnets and longlines were set overnight from 16:00 to 09:00. Sampling in the Nuwejaars River (sample sites $9 \& 10$ ) and Ratel River (sample sites 2 \& 3) was undertaken with a hand-held electro-fishing apparatus, powered by a $220 \mathrm{~V} \mathrm{AC,} 1.8 \mathrm{kva}$ portable generator. Anchovy seine nets operated by two persons were used to collect fishes in pans within the park $(10 \mathrm{~m} \times 1.5 \mathrm{~m} \times 3 \mathrm{~mm})$ as well as in the Heuningnes River $(5 \mathrm{~m} \times 2 \mathrm{~m} \times 3 \mathrm{~mm})$ during the river-health assessment. A dipnet (SASS net) was used to sample fishes in the Pietersielieskloof and Kleinpietersielies rivers as the water was too shallow to use a seine net.

Fishes collected were identified using keys in Skelton (2001) and Whitfield (1998), and counted. Identification of species collected during river-health assessments was based entirely on field observations, whereas identification from SANParks surveys were based predominantly, and in the case of Galaxias zebratus Castelnau, 1861 entirely on assessment of museum voucher specimens now housed at South African Institute for Aquatic Biodiversity (SAIAB) in Grahamstown. (Voucher numbers for specimens collected in ANP: Sandelia capensis $=77372,77379$, 77383, 77384, 77387; Galaxias zebratus (form A) = 77373, 77378, 77386; Galaxias zebratus (form B) = 77385; Mugil cephalus $=77375 ;$ Liza richardsonii $=$ 77376; Gilchristella aestuaria $=77382$; Caffrogobius gilchristi $=77377 ;$ Cyprinus carpio $=77380 ;$ Micropterus punctulatus $=77374,77381)$. Gilchristella aestuaria (Gilchrist, 1913) collected in Soetendalsvlei 


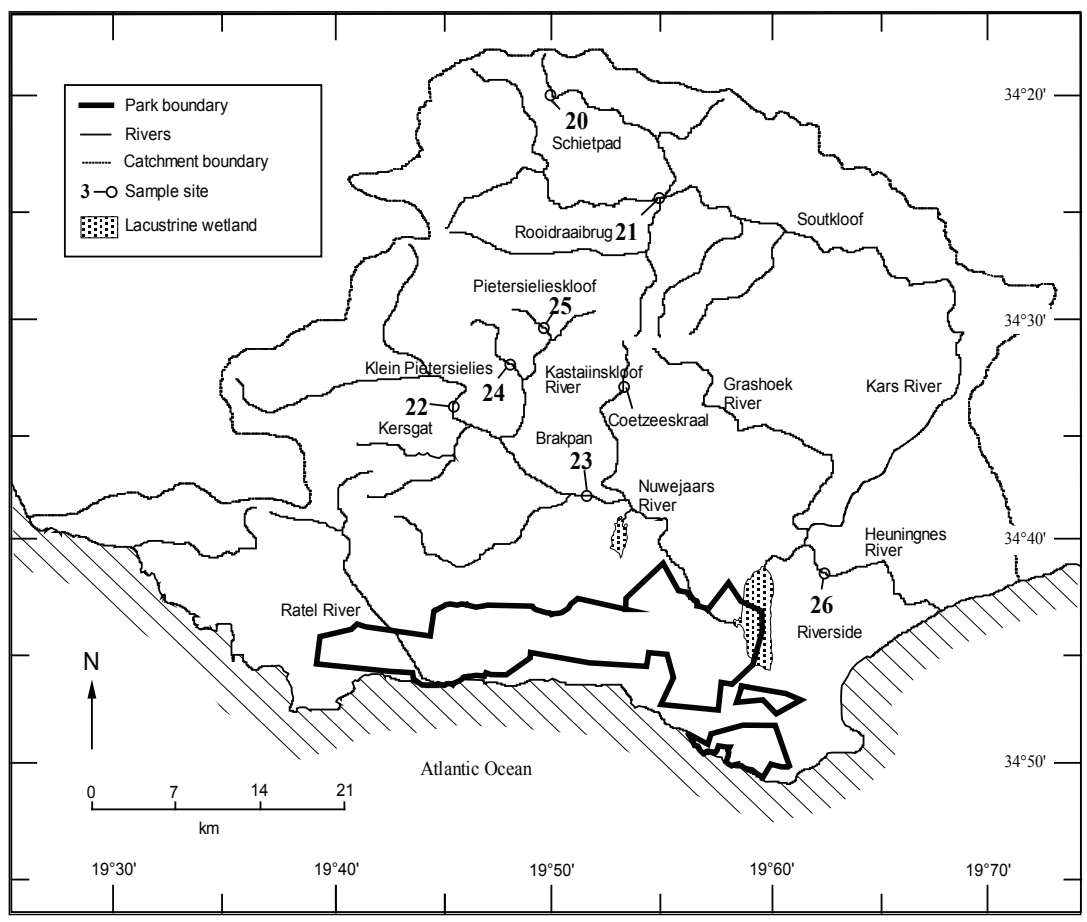

Fig. 2. Map of the Heuningnes catchment showing fish survey sites of the River Health assessment.

were sub-sampled, with live individuals counted in lots of approximately 100 and released.

At the time of writing, Galaxias zebratus is still recognised as a single species, though anatomical differences within the meta population indicate the occurrence of different forms that, with closer investigation, may be accorded full species status (E. Swartz pers. comm.). Two forms were described from specimens collected in ANP, defined here as "form A" and "form B". Galaxias zebratus (form A) is characterised by having an elongated body, small eyes, broad caudal peduncle and distinctive striped body markings, and G. zebratus (form B) characterised by having a deeper body form, large eyes, narrow caudal peduncle, and body markings being either very light or absent (E. Swartz pers. comm.). As species collected outside of ANP were assessed only in the field, no distinction was made between different forms and are referred to here as G. zebratus. For G. zebratus within ANP, distinction is made between the two forms.

Similarly, at the time of writing, Pseudobarbus burchelli Smith, 1841 is still recognised as a single species, though genetic work by Swartz (2005) on the Pseudobarbus group indicates that the population from the Grashoek River in the Heuningnes River system is divergent from other $P$. burchelli populations in the Breede system. Although the Heuningnes population could well, following closer investigation, be accorded full species status (E. Swartz pers. comm.) for consistency this species has continued to be described here as $P$. burchelli.

Observations were made at sample sites within ANP of the distribution of emergent aquatic plants. They were considered to be wide-spread or abundant if established stands occurred on $>50 \%$ of wetland margin, of intermediate abundance if the margin colonised was between $20 \%$ and $50 \%$, and sparse if $<20 \%$ of the margin was colonised. The same proportions were applied to submerged macrophytes and epipsammic algae with respect to the percentage of substratum colonised in sample areas.

Cluster analysis was performed on water quality parameters at the different sites within ANP, using Ward's method and Euclidean metric as distance measure in Statgraphics, version 4.0. 


\section{Results}

\section{Water quality}

The physical and chemical parameters of the wetlands sampled within Agulhas National Park showed wide variability (Table 1). Daytime water temperature varied $11.9^{\circ} \mathrm{C}$ between waterbodies, with the coolest water $\left(<22^{\circ} \mathrm{C}\right)$ occurring in the deep vegetated palustrine wetlands of the Ratel River system, and the warmest $\left(>30^{\circ} \mathrm{C}\right)$ in shallow saline pans such as Springfield Pan \#1, Renosterkop Pan and Melkbospan \# 1. There was large variability in salinity between waterbodies. The most saline water sampled (Agulhas Soutpan) was 990 times that of the least saline (Ratel River \#2). The range in $\mathrm{pH}$ between waterbodies was also wide, with waters in the Ratel River being slightly acidic (6.4-6.8), and pans such as Springfield Pan \# 1 and Die Vleitjies \#2 being strongly alkaline $(\mathrm{pH}=10)$. Water in all endorheic pans was alkaline, with highly saline pans $(>100 \mathrm{~g} / \mathrm{kg})$ being weakly alkaline $(\mathrm{pH} 7.3-$ 7.8) whereas in moderately saline and brackish pans $(<60 \mathrm{~g} / \mathrm{kg})$ alkalinity was generally higher ( $\mathrm{pH} 8.1-10.0)$. Dissolved oxygen was consistently low $(5.2-3.7 \mathrm{mg} / \mathrm{l})$ in the highly saline waterbodies. A wider range in dissolved oxygen values were recorded in moderately saline to fresh waterbodies $(5.2-10.7 \mathrm{mg} / \mathrm{l})$, with dissolved oxygen in most waterbodies being high $(>7 \mathrm{mg} / \mathrm{l})$. Variability in turbidity between waterbodies was very high, with the most turbid waterbody (Die Pan) being 4213 times more turbid than the nearby and least turbid waterbody (Melkbospan \#2).

\section{Ichthyofauna}

Eleven fish species were collected in ANP (Table 1). The species composition in Soetendalsvlei showed a strong marine influence with the collection of two estuarine species (Caffrogobius gilchristi (Boulenger, 1900), Liza richardsonii (Smith, 1846)), and three species ( $G$. aestuaria, Monodactylus falciformis Lacepède, 1800, Mugil cephalus Linnaeus, 1758) which, although occasionally found in coastal rivers (Skelton 2001), occur predominantly in estuaries or inshore coastal waters (Whitfield 1998). No indigenous freshwater fishes were collected in Soetendalsvlei, though four alien freshwater fishes (Cyprinus carpio Linnaeus, 1758, Lepomis macrochirus Rafinesque, 1819, Micropterus salmoides (Lacepède, 1802), Micropterus punctulatus (Rafinesque, 1819)) have established populations. In the Nuwejaars River which flows into Soetendalsvlei, both estuarine (M. cephalus, G. aestuaria) and alien (C. carpio, M. punctulatus) fishes persist, along with the indigenous freshwater Sandelia capensis (Cuvier, 1831). The Ratel River contained two indigenous freshwater fishes ( $S$. capensis, G. zebratus) with $S$. capensis populations also occurring in the lakelike pans (Buffelsjacht and Ratel River Pan) associated with this river system. An isolated population of G. zebratus (form A) occurs in Melkbospan \#2.

In the rivers adjacent to the ANP, 11 species were collected during the River Health assessment (Table 2). All three species of indigenous primary freshwater fishes expected for the region were recorded, including $P$. burchelli. Sandelia capensis and G. zebratus were widespread and fairly common. Both forms (A and B) of Cape Galaxias were recorded, notably in the Pietersielieskloof catchment. Three invasive alien freshwater fishes were recorded, namely C. carpio, L. macrochirus and M. punctulatus. These species are probably more widespread than indicated in the survey, as several sites had deep wide pools where use of the small seine was ineffective. A single site near the Heuningnes estuary at the Struisbaai road bridge was sampled which yielded an unusual catch comprising two primary freshwater fishes, one alien ( $C$. carpio) and one indigenous (S. capensis), and several estuarine-marine species ( $G$. aestuaria, M. falciformis, $C$. gilchristi, Rhabdosargus holubi (Steindachner, 1881) and Solea bleekeri (Boulenger, 1898)).

\section{Wetland classification:}

Cluster analysis revealed four distinctive wetland groups (Fig. 3): 
Table 1

Number of fish specimens per species collected in the Agulhas National Park during December 2003 and March 2004, and physico-chemical parameters at the time of fish sampling. Site numbers as per Fig. 1

\begin{tabular}{|c|c|c|c|c|c|c|c|c|}
\hline 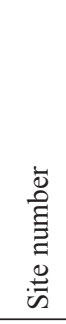 & 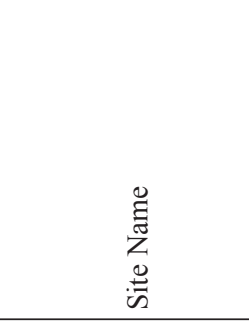 & 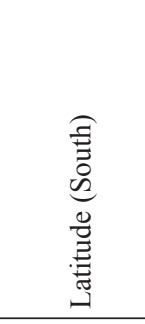 & 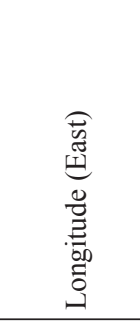 & 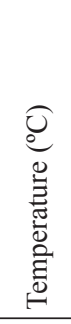 & 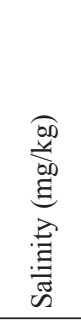 & 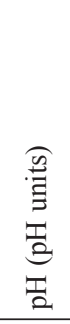 & 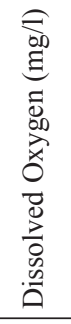 & 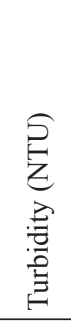 \\
\hline \multicolumn{9}{|c|}{ Group 1: Riverine, palustrine \& lacustrine wetlands } \\
\hline 3 & Ratel River \# 2 & $34^{\circ} 43^{\prime} 58^{\prime \prime}$ & $19^{\circ} 43^{\prime} 10^{\prime \prime}$ & 21.4 & 0.2 & 6.8 & 7.9 & 8.6 \\
\hline 2 & Rater River \# 1 & $34^{\circ} 45^{\prime} 15^{\prime \prime}$ & $19^{\circ} 43^{\prime} 48^{\prime \prime}$ & 24.4 & 0.3 & 6.4 & 7.6 & 7.9 \\
\hline 19 & Ratel River Pan & $34^{\circ} 44^{\prime} 35^{\prime \prime}$ & $19^{\circ} 40^{\prime} 30^{\prime \prime}$ & 20.5 & 0.9 & 7.5 & 8.3 & 264 \\
\hline 17 & Buffelsjag & $34^{\circ} 44^{\prime} 30^{\prime \prime}$ & $19^{\circ} 39^{\prime} 30^{\prime \prime}$ & 21.5 & 5.3 & 8.1 & 8.4 & 9.5 \\
\hline 10 & Nuwejaars River \# 2 & $34^{\circ} 43^{\prime} 28^{\prime \prime}$ & $19^{\circ} 57^{\prime} 40^{\prime \prime}$ & 22.7 & 1.2 & 7.8 & 6.5 & 2.5 \\
\hline 9 & Nuwejaars River \# 1 & $34^{\circ} 43^{\prime} 18^{\prime \prime}$ & $19^{\circ} 57^{\prime} 05^{\prime \prime}$ & 21.4 & 1.8 & 7.7 & 7.2 & 36 \\
\hline 1 & Soetendalsvlei & $34^{\circ} 44^{\prime} 20^{\prime \prime}$ & $19^{\circ} 59^{\prime} 40^{\prime \prime}$ & 23.1 & 1.0 & 7.6 & 7.8 & 13 \\
\hline \multicolumn{9}{|c|}{ Group 2: Brackish endorheic wetlands } \\
\hline 15 & Springfield Pan \# 2 & $34^{\circ} 44^{\prime} 30^{\prime \prime}$ & $19^{\circ} 54^{\prime} 50^{\prime \prime}$ & 25.4 & 3.9 & 8.7 & 10.7 & 3.8 \\
\hline 18 & Drie Vleitjies \# 2 & $34^{\circ} 45^{\prime} 05^{\prime \prime}$ & $19^{\circ} 45^{\prime} 10^{\prime \prime}$ & 22.3 & 9.5 & 10.0 & 9.4 & 3.6 \\
\hline 8 & Melkbos Pan \# 2 & $34^{\circ} 43^{\prime} 20^{\prime \prime}$ & $19^{\circ} 45^{\prime} 30^{\prime \prime}$ & 25.5 & 3.0 & 9.3 & 8.2 & 1.5 \\
\hline 14 & Springfield Pan \# 1 & $34^{\circ} 44^{\prime} 15^{\prime \prime}$ & $19^{\circ} 54^{\prime} 40^{\prime \prime}$ & 32.4 & 7.1 & 10.0 & 9.5 & 5.6 \\
\hline 13 & Soutpan extension & $34^{\circ} 43^{\prime} 35^{\prime \prime}$ & $19^{\circ} 54^{\prime} 40^{\prime \prime}$ & 28.4 & 5.8 & 9.6 & 9.6 & 2.1 \\
\hline 6 & Drie Vleitjies \# 1 & $34^{\circ} 45^{\prime} 00^{\prime \prime}$ & $19^{\circ} 45^{\prime} 20^{\prime \prime}$ & 27.8 & 17.5 & 9.9 & 10.3 & 3.4 \\
\hline \multicolumn{9}{|c|}{ Group 3: Saline endorheic wetlands } \\
\hline 11 & Soutbos Pan & $34^{\circ} 43^{\prime} 23^{\prime \prime}$ & $19^{\circ} 56^{\prime} 35^{\prime \prime}$ & 27.6 & 41.4 & 8.6 & 5.2 & 83 \\
\hline 16 & Renostekop Pan & $34^{\circ} 45^{\prime} 35^{\prime \prime}$ & $19^{\circ} 55^{\prime} 30^{\prime \prime}$ & 30.7 & 52.8 & 8.8 & 7.2 & 6.0 \\
\hline 4 & Rietfontein Pan & $34^{\circ} 44^{\prime} 20^{\prime \prime}$ & $19^{\circ} 44^{\prime} 20^{\prime \prime}$ & 28.9 & 58.5 & 9.2 & 6.4 & 9.2 \\
\hline \multicolumn{9}{|c|}{ Group 4: Highly saline endorheic wetlands } \\
\hline 7 & Melkbos Pan \# 1 & $34^{\circ} 43^{\prime} 15^{\prime \prime}$ & $19^{\circ} 45^{\prime} 20^{\prime \prime}$ & 30.1 & 162.0 & 7.4 & 3.7 & 55 \\
\hline 12 & Agulhas soutpan & $34^{\circ} 43^{\prime} 20^{\prime \prime}$ & $19^{\circ} 55^{\prime} 20^{\prime \prime}$ & 29.7 & 198.0 & 7.3 & 4.8 & 3843 \\
\hline 5 & Die Pan & $34^{\circ} 44^{\prime} 40^{\prime \prime}$ & $19^{\circ} 45^{\prime} 20^{\prime \prime}$ & 27.0 & 112.8 & 7.8 & 5.2 & 6319 \\
\hline
\end{tabular}




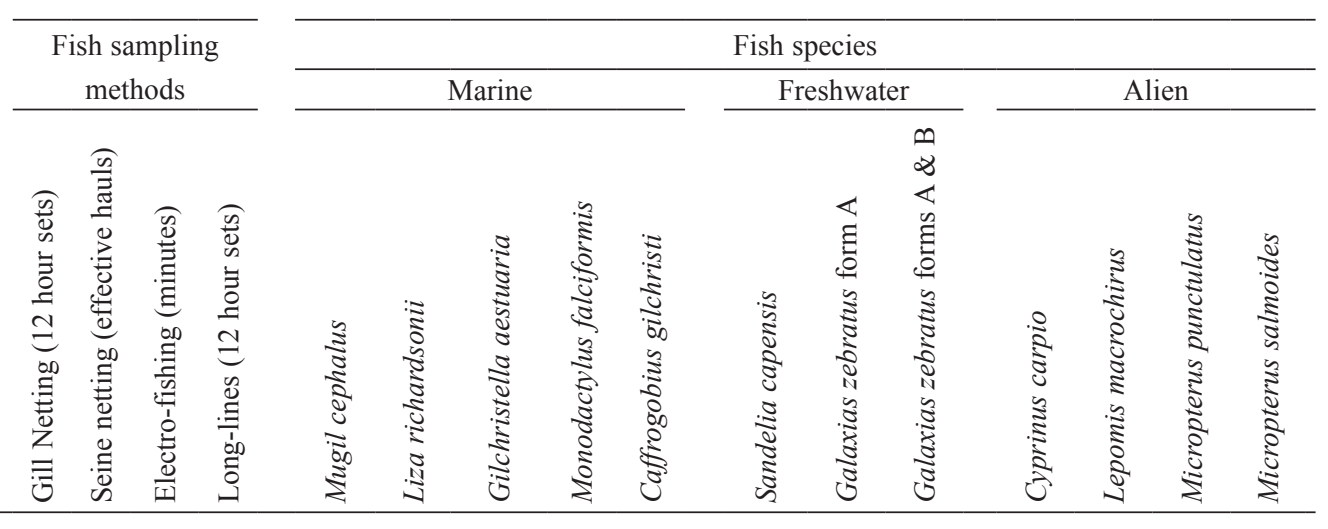

\begin{tabular}{|c|c|c|c|c|c|c|c|c|c|c|c|c|c|c|}
\hline - & - & 15 & - & - & - & - & - & - & 214 & 3 & - & - & - & - \\
\hline - & - & 60 & - & - & - & - & - & - & 40 & - & 58 & - & - & - \\
\hline - & 3 & - & - & - & - & - & - & - & 78 & - & - & - & - & - \\
\hline - & 1 & - & - & - & - & - & - & - & 31 & - & - & - & - & - \\
\hline - & - & 60 & - & 1 & - & 1 & - & - & 15 & - & - & - & - & 1 \\
\hline - & - & 60 & - & 2 & - & 35 & - & - & 24 & - & - & 33 & - & 11 \\
\hline 1 & 2 & - & 1 & 44 & 15 & 4750 & 81 & 1 & - & - & - & 9 & 1 & 25 \\
\hline
\end{tabular}


Group 1. Palustrine, lacustrine and riverine wetlands

Waterbodies in this group include the Ratel and Nuwejaars rivers, and the large (1 $853 \mathrm{ha}$ ) permanently inundated lacustrine Soetendalsvlei, and the deep $(>1 \mathrm{~m})$ palustrine waterbodies of Buffeljacht Pan and Ratel River Pan in the Ratel River system. Salinity in these waterbodies is low $(0.2-5.3 \mathrm{~g} / \mathrm{kg})$, $\mathrm{pH}$ ranges from slightly acid to moderately alkaline ( $\mathrm{pH}$ 6.4-8.1), dissolved oxygen is moderate $(6.5-8.4 \mathrm{mg} / \mathrm{kg})$, and turbidity is highly variable (2-264 NTU) though is low in most waterbodies. Water temperature $\left(20.5-24.4^{\circ} \mathrm{C}\right)$ is substantially lower (approx. $7^{\circ} \mathrm{C}$ ) than that recorded in large, shallow, endorheic wetlands in the region. These wetlands are associated with major drainage lines. Most wetlands support submerged macrophytes, which in some cases (e.g. Ratel River Pan) are abundant, and all have extensive stands of emergent macrophytes, principally Phragmites australis
(Cavanilles) Trinius ex Steudel and Typha capensis (Rohrbach). All waterbodies support fish communities. The Ratel River sites form a subgroup by virtue of waters being acidic $(\mathrm{pH}<6.8)$ and having very low salinity $(<0.3 \mathrm{~g} / \mathrm{kg})$.

\section{Group 2. Brackish endorheic wetlands}

This group of six wetlands consists predominantly of smaller endorheic pans located on the periphery of large highly saline pans, and presumably forming part of the drainage system of these waterbodies. There is large variability in salinity $(3.0-17.5 \mathrm{~g} / \mathrm{kg})$ though in most waterbodies is below $10.0 \mathrm{~g} / \mathrm{kg}$. Waters are characterised by being strongly alkaline ( $\mathrm{pH} 8.7-10.7)$, having high dissolved oxygen $(8.2-10.7 \mathrm{mg} / \mathrm{kg})$ and very low turbidity (2-6 NTU). These wetlands form two subgroups (Fig. 2) which differ principally in terms of water temperature, with Drie Vleitjies \#1, Soutpan extension and Spring-

Table 2

Fish species caught at seven sites on the Heuningness catchment during the October 2005 river-health assessment. Included are average scores for three water quality parameters taken during the seasonal assessment. Site numbers as per Fig. 2

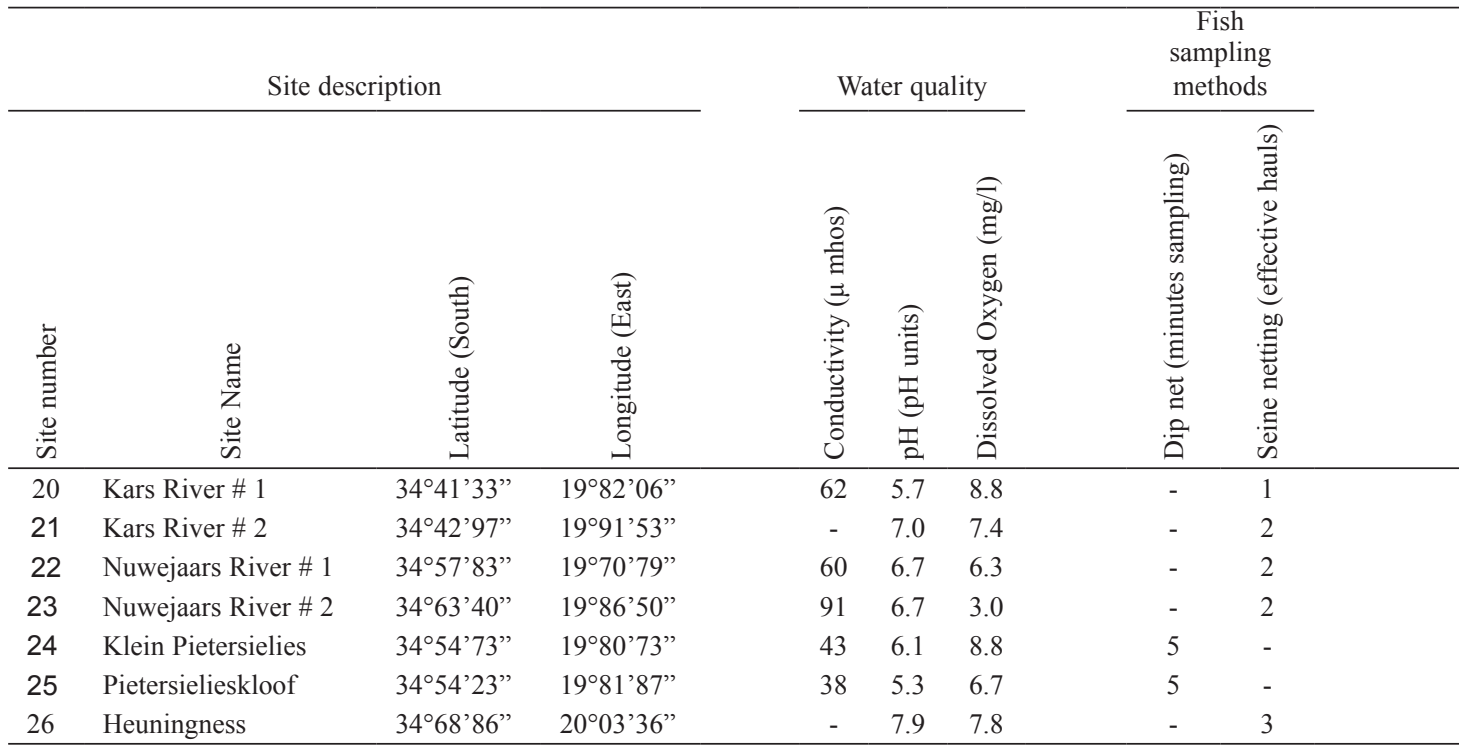




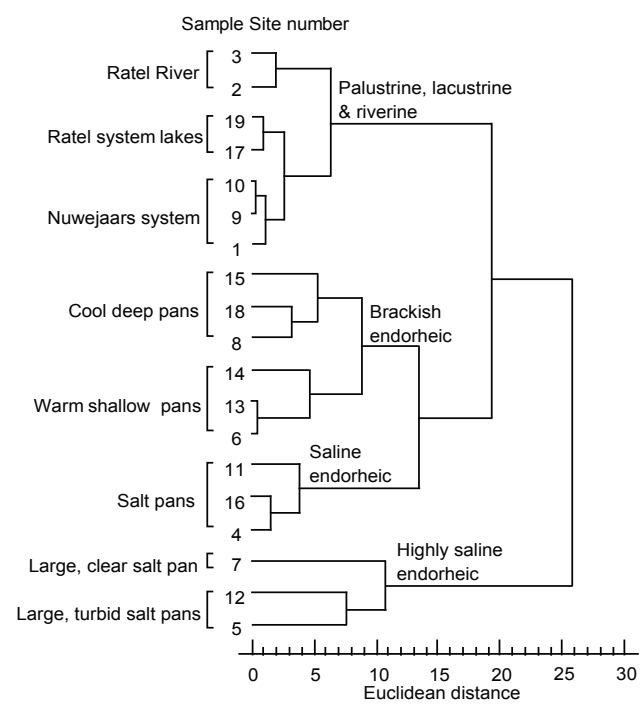

Fig. 3. Classification of wetland systems within Agulhas National Park based physico-chemical variables (water temperature, salinity, $\mathrm{pH}$, dissolved oxygen, turbidity) as determined during fish surveys undertaken in during December 2003 and March 2004. field Pan \# 1 being warmer $\left(27.8-32.4{ }^{\circ} \mathrm{C}\right)$ at the time of sampling than were Melkbos Pan \#2, Drie Vleitjies \#2, and Springfield Pan \#2 (22.3-25.5 $\left.{ }^{\circ} \mathrm{C}\right)$. Submerged rooted macrophytes and/or filamentous algae occur in most waterbodies though are generally not abundant. Emergent macrophytes occur on the margins of most waterbodies, though stands are generally sparse. Fishes occur in one waterbody, namely an isolated population of G. zebratus (form A) in the brackish $(3.0 \mathrm{~g} / \mathrm{kg})$ well-vegetated Melkbos Pan \#2.

Group 3. Saline endorheic wetlands

This wetland group consists of three, small, shallow pans which are geographically removed from the larger pan clusters, and are not obviously associated with any of the major drainage lines. The salinity of waters is high $(41.4-58.5 \mathrm{~g} / \mathrm{kg}), \mathrm{pH}$ is strongly alkaline (8.6-9.2), dissolved oxygen is moderate $(5.2-7.2 \mathrm{mg} / \mathrm{kg})$, and turbidity is moderate to

\begin{tabular}{|c|c|c|c|c|c|c|c|c|c|c|}
\hline \multicolumn{5}{|c|}{ Marine } & \multicolumn{3}{|c|}{ Freshwater } & \multicolumn{3}{|c|}{ Alien } \\
\hline 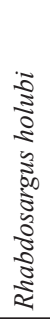 & 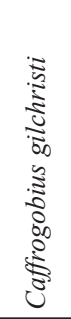 & 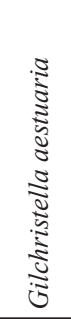 & 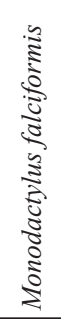 & 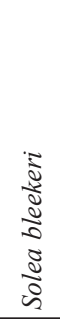 & 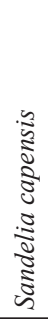 & 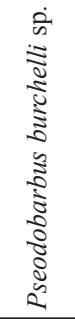 & 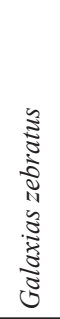 & 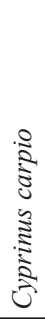 & 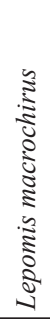 & 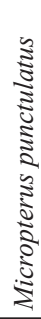 \\
\hline- & - & - & - & - & 7 & $>100$ & 17 & - & - & - \\
\hline- & - & - & - & - & 8 & - & - & - & 8 & 1 \\
\hline- & - & - & - & - & 3 & - & $>50$ & - & 8 & - \\
\hline- & - & - & - & - & - & - & 11 & - & 10 & - \\
\hline- & - & - & - & - & - & - & 5 & - & - & - \\
\hline- & - & - & - & - & - & - & 12 & - & - & - \\
\hline 5 & $>10$ & $>50$ & $>10$ & $>10$ & 6 & - & - & 2 & - & - \\
\hline
\end{tabular}


high (6-83 NTU). Rooted submerged macrophytes are absent, though filamentous algae is abundant. Marginal wetland plants are sparse, consisting predominantly of Juncus and other rush species. Fishes are absent.

Group 4. Highly saline endorheic wetlands

Three waterbodies fall into this group, namely Die Pan, Agulhas Soutpan, and Melkbos Pan \# 1. These are large, shallow $(<1 \mathrm{~m})$ pans characterised by waters which are highly saline (112.8-198.0 g/kg), alkaline ( $\mathrm{pH} 7.3-$ 7.8 ), with dissolved oxygen levels that are very low $(3.7-5.2 \mathrm{mg} / \mathrm{kg})$ and turbidity very high (55-6319 NTU). The substratum consists of fine, grey-white sediments which are easily disturbed and possibly contribute to periodic high turbidity levels in the shallow waters. Both submerged and emergent aquatic plants appear to be largely absent, as are fishes.

\section{Discussion}

Comparative water quality assessments (salinity, $\mathrm{pH}$, turbidity) undertaken in 13 Agulhas wetlands in earlier studies (Silberbauer \& King 1991; Jones et al. 2000) demonstrate, in most cases, similar ranges for wetland groups despite seasonal differences in sampling. Substantial differences with this study were that Jones et al. (2000) reported Renosterkop Pan to be both highly saline ( $>100 \mathrm{~g} / \mathrm{kg}$ ) and turbid (203 NTU), and Silberbauer \& King (1991) reported the three pans (Melkbos Pan \# 1; Agulhas Soutpan; Die Pan) categorised in this study as highly saline $(>100 \mathrm{~g} / \mathrm{kg})$ to be only moderately saline $(16,39 \& 25 \mathrm{~g} / \mathrm{kg}$ respectively). Furthermore, these same three pans were found by Jones et al. (2000) to be moderately turbid (31-52 NTU) compared to the extremely high turbidity recorded in 2003. High variability in water chemistry, particularly salinity, in saline endorheic wetlands is likely to be a result primarily of the annual inundation/drying regime, and suggests that the distinction between saline (Group 3) and highly saline (Group 4) wetlands (Fig. 2) may be an artefact of seasonspecific sampling rather than reflecting a fundamental difference in physico-chemical characteristics. Jones et al. (2000) grouped Agulhas wetlands primarily on geographical similarities, suggesting that wetlands in the same area frequently share characteristics. The present data indicate that hydrological characteristics may be a more informative means of classifying Agulhas wetlands, particularly with respect to the occurrence of biota such as fishes. However, longer term assessment of the physico-chemical properties of Agulhas wetlands, incorporating both seasonal and annual variability, is needed for more informative classification and characterisation of wetland types.

Few published data exist on ichthyofauna of the Agulhas area. Bickerton (1984) cites unpublished reports on fishes previously collected in Soetendalsvlei (cf. Cape Piscatorial Society 1937; Barham 1968; Louw 1968; McVeigh 1980), with the resultant species count differing from current surveys in respect of Lithognathus lithognathus (Cuvier, 1830 ) being previously recorded, and the new record of $C$. gilchristi. Both L. lithognathus and $C$. gilchristi have been recorded in low salinity waters $(<3 \mathrm{~g} / \mathrm{kg})$ (Whitfield 1998) though they are not species commonly associated with the lower reaches of freshwater systems, as are the other marine fishes recorded in Soetendalsvlei (Skelton 2001). It is thus not expected that either species would be common in the predominantly freshwater Soetendalsvlei.

All three indigenous freshwater fish species expected to occur in the Agulhas plain, namely $P$. burchelli, G. zebratus and $S$. capensis were recorded, with populations of the latter two species occurring within ANP.

Published records indicate G. zebratus as the only fish species in the Ratel River system (Cape Department of Nature and Environmental Conservation 1984). However, the occurrence of $S$. capensis within the Ratel River and associated palustrine pans is not unexpected given that is has been recorded in adjacent systems (SAIAB species distribution database). The comparatively high abundance of $S$. capensis in the Ratel system can possibly be ascribed to the wide habitat tolerance 
of this species, particularly with respect to the seasonality of waterbodies (Jubb 1967), combined with the apparent absence of alien predators in the Ratel River.

The occurrence of G. zebratus (form A) in Melkbos Pan \#2 is unusual, being the only fish population in an endorheic pan in Agulhas National Park. There is no information on how this species came to occur in this wetland. In the absence of any records suggesting that this unusual distribution is the result of introduction by humans, the conservation of this isolated population should be afforded high priority.

The distribution of $P$. burchelli is given by Cape Department of Nature and Environmental Conservation (1984) and Skelton (1988) to include the Heuningnes River, which concurs with a species distribution records from the 1940s given by Gaigher (1978). Cambray \& Stuart (1985) failed to collect specimens during 1980, though recent surveys in 2004 yielded specimens from the uppermost reaches of the Grashoek River in the Heuningnes River system (Swartz 2005). This assessment yielded new distribution records from the upper Kars River. Furthermore, in February 2006, a local farmer on the property Coetzeeskraal, next to the Kastaiingskloof River (Fig. 2), requested that CapeNature remove indigenous fish from a small offstream dam that was drying up. This dam receives flow from the river via a furrow. Seine netting yielded a thriving community of P. burchelli, G. zebratus and $S$. capensis, suggesting that these species may still be present in the Kastaiinskloof River. The absence of $P$. burchelli from survey sites in the remainder of this system is a major cause for concern and appears associated with the presence of the piscivorous M. punctulatus, and major habitat damage caused by the floods of February 2005.

Three invasive alien freshwater fishes were recorded during the survey, namely $C$. carpio, L. macrochirus and M. punctulatus. The latter two species are widespread and common, especially in the larger rivers.
The date and reason for the introduction of C. carpio is uncertain, although it is known that this species was extensively stocked as an angling and food fish into rivers across the South Africa in the late 1800s and early 1900s (De Moor \& Bruton 1988). Cyprinus carpio can be detrimental to indigenous fishes when present in large numbers in that it consumes the eggs of other fishes, and can cause habitat degradation by removing aquatic plants and increasing turbidity (De Moor \& Bruton 1988). Cyprinus carpio may be more widespread than these surveys reflect and future fish surveys should utilise gill nets in the bigger deeper pools.

Micropterus punctulatus was introduced into the Nuwejaars River at Elim in 1940 (Harrison 1977). De Moor \& Bruton (1988), however, suggest that its preference for large, turbid rivers and intolerance of low $\mathrm{pH}$ waters will exclude it from establishing populations in south coastal drainage rivers, where environmental conditions would, for the most part, be unfavourable. Distribution maps in Skelton (2001) do not indicate M. punctulatus as occurring in the Agulhas region, though its continued occurrence and now relatively high abundance in Soetendalsvlei and associated rivers indicate that this invasive alien is well established in the lower Nuwejaars and Kars rivers.

It is likely that L. macrochirus were stocked into the Heuningnes system shortly after the introduction of M. punctulatus. Lepomis macrochirus were introduced into South Africa as a fodder fish for bass, when it became apparent that bass had eliminated the smaller indigenous fish species, and thus required an alternative prey source. This species, especially when abundant, can have a major impact on smaller indigenous fishes through competition and predation (De Moor 1988). It is regarded as a pest species as it has negligible angling value while causing considerable ecological damage in certain areas.

Where these alien species occur, their impact on P. burchelli and S. capensis has likely been severe, resulting in poor recruitment and localised extirpations. Galaxias zebratus 
seems to have fared better than the other two species, especially in rivers with abundant submerged aquatic plants, where it could escape predation due to its cryptic colouration and small size.

One additional freshwater fish species, namely Anguilla mossambica Peters, 1852 could potentially occur in ANP and surrounds. The natural range of $A$. mossambica on the African continent includes East Coast rivers from Kenya to Cape Agulhas (Skelton 2001). The ANP rivers would consequently be at the southernmost range of $A$. mossambica which could possibly result in it being uncommon, and hence not yet recorded in the study area.

\section{Recommendations}

The following recommendations are suggested to improve conservation of freshwater fish and wetlands in the Agulhas area:

- Conservation agencies should endeavour to improve public awareness of the detrimental consequences of introducing alien fishes into dams and rivers. As an alternative to alien fishes, local indigenous fishes can be stocked into dams in the catchment. This action should form part of a documented recovery program for these fishes.

- Efforts should be made to improve the conservation status of areas where $P$. burchelli still occurs. These could include land purchase and stewardship arrangements. Land-owner awareness of these fishes is a critical factor.

- The eradication of invasive alien vegetation from riparian zones and wetlands is a priority for restoring flow and rehabilitating severely and moderately invaded systems.

- Fish populations should be monitored on a regular basis, and where required information collected, or specimens retained, that would facilitate taxonomic identification and reassessment of indigenous freshwater species.

\section{Acknowledgements}

Thanks are due to Eddy Kivett, Suzaan Kritzinger and Bronwyn Botha for assistance with the field surveys in Agulhas National Park. Verification of taxa by Dr. E. Swartz of SAIAB is gratefully acknowledged. Riki de Villiers of CapeNature prepared Fig. 2. We are also grateful to Dr. J. Cambray, Dr. E. Swartz and one anonymous reviewer for their critical comments on an earlier version of the manuscript.

\section{References}

BARHAM, W.T. 1968. Report on survey of Zoetendalsvlei Lake, district of Bredasdorp. CPA Department of Nature and Environmental Conservation. Unpublished Report.

BICKERTON, I.B. 1984. Heuningnes (CSW 19). Report No. 25. In: HEYdorN, A.E.F. \& J.R. GRINDLEY (eds.). Estuaries of the Cape. Part II: Synopsis of available information on individual systems. Stellenbosch: Council for Scientific and Industrial Research (CSIR Research report; no. 424).

CAPE DEPARTMENT OF NATURE AND ENVIRONMENTAL Conservation. 1984. Freshwater Fishes of the Cape. Cape Town: Cape Department of Nature and Environmental Conservation. (Cape Conservation Series; no. 5).

Cape Piscatorial Society. 1937. The most southerly lake in Africa: Zoetendals Vlei, about five miles from Cape Agulhas, Bredasdorp Division, Cape Province. Circular 27.

CARR, A. 2005. Late quarternary environmental change on the Agulhas plain, winter rainfall zone, South Africa. PhD Thesis, University of Sheffield, Sheffield.

Cole, N.S., A.T. Lombard, R.M. Cowling, D. Euston-Brown, D.M. Richardson \& C.E. HeiJNIS. 2000. Framework for a conservation plan for the Agulhas Plain, Cape Floristic Region, South Africa. Cape Town: University of Cape Town, Institute for Plant Conservation. (IPC Report 0001).

Cowling, R.M. \& P.M. Holmes 1992a. Endemism and speciation in a lowland flora from the Cape Floristic Region. Biological Journal of the Linnaean Society 47:367-383.

Cowling, R.M. \& P.M. Holmes. 1992b. Flora and vegetation. Pp. 23-63. In: Cowling, R.M. (ed.). The ecology of the Fynbos: nutrients, fire and diversity. Cape Town: Oxford University Press.

Cowling, R.M. \& P.J. MustarT. 1994. Vegetation and conservation report for the Southern Overberg structure plan. University of Cape Town, Institute for Plant Conservation. Unpublished Report.

Cowling, R.M. \& E.T.F. WitKowsKI. 1994. Convergence and non-convergence of plant traits in climatically and edaphically matched sites in Medi- 
terranean Australia and South Africa. Australian Journal of Ecology 19: 220-232.

Cowling, R.M., B.M. Campbell, P. Mustart, D.J. MCDOnAld, M.L. Jarman \& E.J. Moll. 1988. Vegetation classification in a floristically complex area: the Agulhas Plain. South African Journal of Botany 54:290-300.

Cowling, R.M., R.L. Pressey, A.T. Lombard, P.G. DESMET \& A.G. Ellis. 1999. From representation to persistence: requirement for a sustainable reserve system in the species rich Mediterraneanclimate deserts of southern Africa. Diversity and Distributions 5(1):51-71

De Moor, J. \& M.N. Bruton. 1988. Atlas of alien and translocated indigenous aquatic animals in southern Africa. Pretoria: Council for Scientific and Industrial Research. (South African National Scientific Programmes Report 144).

De Villiers, A.L. 1988. Micro frog. Pp. 29-32. In: Branch, W.R. (ed.). South African Red Data Book-reptiles and amphibians. Pretoria: Council for Scientific and Industrial Research (South African National Scientific Programmes; report no. 151).

Gaigher, I.G. 1978. The distribution, status and factors affecting the survival of indigenous freshwater fishes in the Cape Province. Cape Department of Nature and Environmental Conservation. Unpublished Report.

Goudie, A.S. 1991. Pans. Progress in Physical Geography 15: 221-237.

HARRISON, A.C. 1977. The early transactions of the Cape Piscatorial Society. Part VI. Piscator 100: 66-68.

Impson, N.D., I.R. Bills, J.A. CAmbray \& A. LE Roux. 1999. The primary freshwater fishes of the Cape Floristic Region: conservation needs for a unique and highly threatened fauna. CapeNature Internal Report. 26pp.

Jones, M.G.W., G.D.P. VAN NieUWENHUIZEN \& J.A. DAY. 2000. Selecting priority wetlands for conservation measures. The Agulhas Plain as a case study. University of Cape Town. Unpublished Report.

JubB, R.A. 1967. Freshwater fishes of southern Africa. Cape Town: Balkema.

Low, A.B. \& A.G. Rebelo. 1996. Vegetation of Southern Africa, Lesotho, and Swaziland. Pretoria: Department of Environmental Affairs and Tourism.

Louw, R.J. 1968. Survey of fish population. Soetendals Vlei, Voël Vlei. District Bredasdorp. CPA Department of Nature and Environmental Conservation. Unpublished Report.

Marshall, T.R. \& J.T. HARMSE. 1992. A review of the origin and propagation of pans. South African Geographer 19: 9-21.

MCVEIGH, S.J. 1980. Inspection at Soetendalsvlei, Bredasdorp district. CPA Department of Nature and Environmental Conservation. Unpublished Report. 6pp.
Mustart, P., R.M. Cowling \& J. Albertyn. 1997. Southern Overberg. Cape Town: Botanical Society of South Africa (South African Wild Flower Guide; no. 8).

NoBle, R.G. \& J. Hemens. 1978. Inland water ecosystems in South Africa - a review of research needs. Pretoria: Council for Scientific and Industrial Research. (South African National Scientific Programmes; report no. 34).

RAIMONDO, J.P. \& J.A. BARKER. 1988. ESKOM nuclear site investigation: Southern Cape region, regional study, Gansbaai to Agulhas. University of Cape Town, Environmental Evaluation Unit. Unpublished Report.

Rebelo, A.G. 1992. Red Data Book species in the Cape Floristic Region: threats, priorities and target species. Transactions of the Royal Society of South Africa 48:55-86.

Rebelo, A.G. \& W.R. Siegfried. 1992. Where should nature reserves be located in the Cape Floristic Region, South Africa? Models for the spatial configuration of a reserve network aimed at maximizing the protection of floral diversity. Conservation Biology 6:243-252.

Ryan, P.G., L.G. Underhill, J. CoOper \& M. WALtNER. 1988. Waders (Charadrii) and other waterbirds on the coast, adjacent wetlands and offshore islands of the southwestern Cape Province, South Africa. Bontebok 6:1-19

Shaw, P.A. \& D.S.G. Thomas. 1997. Playas, pans and salt lakes. Pp. 293-317. In: Tномаs D.S.G. (ed.). Arid Zone Geomorphology. London: Wiley.

Silberhauer, M.J. \& J.M. KING. 1991. Geographical trends in the water chemistry of wetlands in the south-western Cape Province, South Africa. South African Journal of Aquatic Science 17(1/2): 82-88.

SKELton, P.H. 1988. A taxonomic revision of the redfin minnows (Pisces, Cyprinidae) from southern Africa. Annals of the Cape Provincial Museum 16(10): 201-307.

SKelton, P.H. 2001. A complete guide to the freshwater fishes of southern Africa. Cape Town: Struik.

Swartz, E.R. 2005. Phylogeography, phylogenetics and evolution of the redfins (Teleostei, Cyprinidae, Pseudobarbus) in southern Africa. PhD thesis, University of Pretoria, Pretoria.

Thwaites, R.N. \& R.M. Cowling. 1988. Soil-Vegetation relationships on the Agulhas plain, South Africa. Catena 15: 333-345.

Whitfield, A.K. 1998. Biology and ecology of fishes in southern African estuaries. Grahamstown: J.L.B. Smith Institute of Ichthyology (Ichthyological Monographs of the J.L.B. Smith Institute of Ichthyology; no. 2).

Willis, C.K., R.M. Cowling \& A.T. Lombard. 1996. Patterns of endemism in the limestone flora of South African lowland fynbos. Biodiversity \& Conservation 5:55-73. 